\title{
INACTION IS ALSO ACTION: ATTEMPTING TO ADDRESS PĀKEHĀ PARALYSIS
}

Joe Citizen

\section{BEING OPEN TO CHANGE}

As a Pākehā creative arts tutor and practice-led researcher working for the regional polytechnic Waikato Institute of Technology (Wintec), I have often been aware of what Tolich (2002) calls 'Pākehā paralysis': the tendency by Pākehā not to engage with Māori because it is 'too hard' due to an inability "to distinguish between their role in Māori-centred research and their role in research in a New Zealand society, which involves Māori among other ethnic groups." (Tolich, 2002, p. 176). The default position is often one of avoidance, or worse, positioning Māori within a 'mainstream' education framework that frequently makes universalist assumptions in a manner that has been called "whitestreaming" (Denis, 1997, as cited in Milne, 2013, p. 3). Intellectually being aware of these issues is, however, quite different to doing something about it as a Pākehā schooled and practising within the same liberal humanist traditions one is attempting to be critical of (Jones, 2017, p. 189). Some may even reasonably ask if it is possible to step outside of oneself, to escape an education system where one's position and privilege is predicated by values that emphasise expertise as a foundation for authority. To really attempt partnership as a Pākehā working with Māori, it is necessary to change oneself and to be open to the possibility of such changes. Such a process is, by necessity, uneasy, full of awkwardness and discomfort, as one realises that Pākehā foundational understandings of the world are not universal and cannot be taken for granted.

\section{CHANGE IN THE REAL WORLD}

In reflection, it was perhaps with some naivety, when at the end of 2016, I approached Wintec's Director Māori, Hera White, and asked if the Mãori Achievement Unit would countenance a partnership project with myself as part of my then PhD candidature. Her companion laughed when I asked, but Hera just nodded to herself and remarked that "opportunities like this don't come along very often." Then to the surprise of both myself and her companion, she agreed to the proposal. The idea was to attempt to embed Wintec's Te Ngāwhā Whakatupu (Māori capability framework) into a real-world multidisciplinary collaborative project, where students and staff would help to make a 6.8 metre interactive waka sculpture that would stand on the banks of the Waikato River as a permanent public artwork. The objectives of Te Ngāwhā Whakatupu are a "commitment to Māori success, ngā huatanga Māori - Māori cultural identity, mātauranga Māori - Māori world view and kaupapa Māori" (Te Ngāwhā Whakatupu, p.2, 2013). This framework identifies several core 'values' that Wintec staff are encouraged to build competency in, ako, te tiriti, ahurea, tikanga, and te reo. Woven into the tangible sculpture concept was the use of interactive sound and lighting compositions that would be informed by an Internet of Things sensor network, to refer to the seven stars of Matariki as recognised by Waikato-Tainui. 


\section{RELATIONSHIPS AS ONGOING PROCESS}

It is fair to say that at the time I had little idea of the journey I was about to embark on, for despite my good intentions it quickly became clear that in practice I had only a rudimentary understanding of te ao Māori. I needed the Māori Achievement Unit much more than they needed me as Wintec had declared a 'whole of organisation approach' towards embedding Te Ngāwhā Whakatupu into teaching and learning. Nonetheless, Hera agreed to the formation of a new research group called He waka eke noa after the famous whakatauki (proverb), which literally refers to being in the same boat together.

In retrospect, I realise that Hera had taken my proposal seriously because she had observed my practice over the previous ten years. As a former master's student, one of my early jobs at Wintec had been to work as the arts archivist for the library. I first met her in 2008 when l'd realised that the Excel spreadsheet approach favoured by Finance to categorise artworks as assets couldn't be applied to taonga. At that time, she'd introduced me to Kaumātua Tame Pokaia, who had since then advised me on various research and teaching projects l'd been involved with. In other words, our whanaungatanga (relations) had already been established when I had proposed the project to her - it was not as if I was a complete stranger.

\section{MĀORI WAYS OF BEING AND DOING AS NORMAL}

My realisation of the importance of whanaungatanga was, in the event, a crash course in coming face-to-face with my own ignorance. Having publicly announced the project, enlisted the goodwill of my engineering colleagues and set in train the requisite processes for a permanent public artwork with Hamilton City Council, it was agreed that a whakawhanaungatanga barbeque, in early February 2017, would give students and staff working on the project a chance to meet each other. It was a relief to finally start the process and I was anxious to see the first of the scheduled production milestones now become a reality. Having made and taught community-based filmmaking for over twenty years, I felt confident leading a collaborative project of this magnitude. A month later, when one of the tutors and his class had to drop out of the project, it was relatively simple for me to find a replacement tutor and a new class to take his place. It was only when I breezily announced this to one of my colleagues in the Māori Achievement Unit that I realised what I thought was a normal thing to do was actually the exact opposite.

I was completely unprepared for her rage. How dare I introduce people to the project who they had not met, nor who had had the opportunity to meet everyone else? It is extremely rare to be shouted at in a professional educational context by a colleague, and I was utterly shocked. I had no idea what I had done wrong, but quickly realised that not only had I caused offence, but that in all likelihood the entire enterprise was in now jeopardy. I made my apologies and left, convinced that the damage was irreparable.

Later I was to discover that whanaungatanga refers to "the primacy of kinship bonds in determining action and the importance of genealogy in establishing rights and status" (Hēnare, 20I5, p. 9l). It has also been described as the "process of establishing relationships, relating well to others" (Maori Dictionary, n.d.), or literally, to "become as family."

\section{CONFRONTING ONE'S OWN CULTURAL ASSUMPTIONS}

Reflecting on this incident, it became clear to me I was not relating well to my Māori Achievement colleagues nor with the wider project partners. I had taken it for granted that I was the one leading the project, and that my 'top down' task-focussed production management approach was normal. These assumptions completely blinded me to the core tenets of the partnership agreement in the first instance, which was to embed the values of Te Ngāwhā Whakatupu into everyday practice. It is one thing to read about structural discourse from a distance but quite another to realise that one's own assumptions are part of that discourse. I was neither relating well to others nor behaving like a member of a family, and to extend the common analogy of the Māori-Pākehā partnership as being 
like a personal relationship, my actions could be described as thoughtless as best. When such thoughtlessness is repeated or brushed aside in favour of meeting other needs such as a rigid approach to allocable time, then such behaviour is an attempt to exert control. For at the heart of these actions, motivated by anxiety or otherwise, sit assumptions about power with the 'who' and 'what' of decision-making being taken for granted. Such realisations are uncomfortable to consider and because our shared goals were to embed Māori ways of being and doing as the default mode for teaching and learning this entailed confronting my ideas about cultural equivalency and equality head-on. Being a good partner means not taking one's own cultural assumptions for granted, and this includes those individualistic liberal humanist understandings of what intercultural partnership is.

\section{WOVEN INTO WHĀNAUNGATANGA}

Extension of the personal partnership analogy to its fullest extent now became extremely challenging, as slowly it dawned on me that far from 'solving the problem', I was, in an institutional context, part of the problem:

Dominant and controlling partners do not relinquish power easily. Nor do they readily see themselves as part of the problem. They find it threatening to acknowledge that their minority treaty partner has a language, culture, curriculum and pedagogy that are all alive and well, with their own integrity, but rendered largely invisible within our school system. (Glynn, Berryman, Walker, Reweti, \& O'Brien, p.5, 200I).

Comprehension of my own complicity within the interwoven field of relations was something of a revelation because it meant taking responsibility for my actions in a way that did not 'naturally make sense.' Any sense of neutrality or 'standing at a distance' became untenable, for when one realises that one is in a partnership, then an absence of action becomes an action as well. That I was simultaneously researching entanglement and performativity became manifestly ironic because my agency was clearly one of many agencies that co-constituted the continuously unfolding phenomena at the time (Citizen, 2019).

\section{PĀKEHĀ FEELINGS OF AWKWARDNESS}

A shift now occurred without my really noticing it. Previously at ease and confident in my abilities, I began to feel like a stranger - awkward and out of place. How then, must some of my students feel, when they come into a teaching and learning environment that takes particular ways of being and doing for granted? This awkwardness is not pleasant, and I can quite understand why some of my Pākehā colleagues altogether avoid engaging with Māori culture in any meaningful sense. Yet it seems to me that such feelings of awkwardness and discomfort are also part of the partnership process, not to be celebrated in themselves but to enable those moments whereby one realises the discomfort for what it is and thereby introduces new possibilities into situations. For when one feels conscious of being an awkward stranger, then rather than simply reacting, one's actions are able to become more considered.

\section{WHĀNAUNGATANGA INFORMS PARTNERSHIP}

Recognising how whānaungatanga informs the partnership paradigm as process rather than event leads to a reconsideration of what partnership might look like. When it became clear that I too was on a learning journey, then disestablishing my authority amongst the complexity of relationships became obvious. Identifying Māori Achievement as the central partner and positioning myself as one of many other partners in orbit around them became an essential next step. Rather than staking any claim to leading the project or having an authority over knowledge that did not belong to me, I could act within an existing framework as a co-learner amongst other colearners. Te Ngāwhā Whakatupu could now operate as it was intended, as a set of values to be embedded into practice. Such a move makes no sense when viewed from the one-to-one individualistic manner that partnership is commonly understood as being within Pākehā traditions but it makes much more sense when viewed from a collective approach that puts the goals of the endeavour first. 


\section{EDUCATOR AS CO-LEARNER}

That the public art sculpture named Tōia Mai by Kaumātua Tame Pokaia now stands on the Western bank of the Waikato river at Hamilton's Ferrybank reserve is mainly due to a whole of organisation approach that puts the values of Te Ngāwhā Whakatupu into practice. Positioning myself within a partnership paradigm where 'partnership' is not grounded by my own cultural understanding ultimately ensures that I can more authentically engage with what Te Tiriti o Waitangi can mean for teaching and learning in an actual embodied manner. As a tertiary educator attempting to understand what ako means beyond the mantra that 'teaching and learning is reciprocal' is much more potent when approached from a co-learner's perspective. Instead of having to be an authority all the time, I can now appreciate that students know much more than I do in any number of fields. To approach Māori society as something of a stranger means to acknowledge not only my own sense of awkwardness but, fundamentally, the multiplicity of differences between Māori and Pākehā ways of doing and being that are often ignored or brushed over within institutional discourses. My appreciation of tikanga has similarly increased, not only as a means by which this awkwardness of being can be safely navigated but as a recognisable framework where existing whanaungatanga is acknowledged and nurtured. As a respectful stranger in a land that is not as familiar as the worlds in which I previously took for granted as being normal, te reo Māori has enriched my life in ways that I had not thought possible. In summary, when educators become co-learners not only do students find us more approachable, but their learning becomes self-motivated as their existing expertise is acknowledged.

\section{ACKNOWLEDGEMENTS}

My acknowledgements to Wintec Māori Achievement, and all who were part of this amazing waka journey. Ngā mihi nui.

Joe Citizen's practice-led creative research, located at the intercultural space between Māori and Pākehā in Aotearoa New Zealand, mainly explores some potential parallels and synergies between the metaphysics of te ao Māori and te ao Pākehā. By seeking to identify Māori and Pākehā metaphysical strands that challenge human exceptionalism in the production of knowledge, he reassesses aesthetics beyond traditionally Western claims of it being solely a human practice.

(D) https://orcid.org/0000-0002-3805-1829

\section{REFERENCES}

Citizen, J. (2019). Tōia Mai: Speculating on art and reality at the hyphen in Aotearoa-New Zealand. Unpublished PhD thesis. Auckland University of Technology, Auckland, New Zealand.

Glynn, T., Berryman, M., Walker, R., Reweti, M., \& O'Brien, K. (200I, July). Partnerships with Indigenous people: Modifying the cultural mainstream. Keynote address at Partnerships in Educational Psychology Conference, Brisbane, Australia.

Hēnare, M. (20I5). Tapu, mana, mauri, hau, wairua: A Māori philosophy of vitalism and cosmos. In C. Spiller, \& R. Wolfgramm, (Eds.), Indigenous spiritualities at work: Transforming the spirit of enterprise. (Ist ed., pp. 77-98). Information Age Publishing.

Jones, A. (2017). Dangerous liaisons: Pākehā, kaupapa Māori, and educational research. In T. Hoskins, \& A. Jones, (Eds.), Critical conversations in kaupapa Māori. Wellington, Aotearoa-New Zealand: Huia Publishers.

Maori Dictionary. (n.d.). Retrieved from: https://maoridictionary.co.nz/

Milne, A. (2013). Colouring in the White Spaces: Reclaiming Cultural Identity in Whitestream Schools. Unpublished PhD thesis. University of Waikato, Hamilton, New Zealand.

Tolich, M. (2002). Päkehā "paralysis": Cultural safety for those researching the general population of Aotearoa. Social Policy Journal of New Zealand. (19), 164-178.

Waikato Institute of Technology. (2013). Te Ngāwhā Whakatupu. Hamilton, New Zealand: Author. 